\title{
Hyperfunctioning thyroid cancer: a five-year follow-up
}

\author{
Carcinoma de tireoide hiperfuncionante: seguimento de cinco anos
}

Monalisa Ferreira Azevedo', Luiz Augusto Casulari'

${ }^{1}$ Serviço de Endocrinologia, Hospital Universitário (HUB), Universidade de Brasília (UnB), Brasília, DF, Brasil

Correspondence to:

Monalisa Ferreira Azevedo Serviço de Endocrinologia, HUB, UnB SGAN 605, Prédio Novo de Ambulatórios, Térreo, Asa Norte 70840-901 - Brasília, DF, Brasil monalisa@unb.br

Received on Aug/7/2009 Accepted on Oct/16/2009

\section{SUMMARY}

Differentiated thyroid cancer rarely occurs in association with hyperfunctioning nodules. We describe a case of a 47-year-old woman who developed symptoms of hyperthyroidism associated with a palpable thyroid nodule. Thyroid scintigraphy showed an autonomous nodule, and fine-needle aspiration biopsy was suggestive of papillary carcinoma. Laboratorial findings were consistent with the diagnosis of hyperthyroidism. The patient underwent thyroidectomy and a papillary carcinoma of $3.0 \times 3.0 \times 2.0 \mathrm{~cm}$, follicular variant, was described by histological examination. The surrounding thyroid tissue was normal. Postoperatively, the patient received $100 \mathrm{mCi}$ of ${ }^{131}$ I, and whole body scans detected only residual uptake. No evidence of metastasis was detected during five years of follow-up. Hot thyroid nodules rarely harbor malignancies, and this case illustrated that, when a carcinoma occurs the prognosis seems to be very good with no evidence of metastatic dissemination during a long-term follow-up. Arq Bras Endocrinol Metab. 2010;54(1):78-80

\section{SUMÁRIO}

O câncer diferenciado de tireoide raramente ocorre em associação a nódulos hiperfuncionantes. Foi descrito aqui o caso de uma paciente de 47 anos de idade que desenvolveu sintomas de hipertireoidismo associados a um nódulo tireoidiano palpável. A cintilografia da tireoide mostrou tratar-se de um nódulo autônomo, e a biópsia por punção aspirativa por agulha fina foi sugestiva de carcinoma papilar. Os achados laboratoriais foram consistentes com o diagnóstico de hipertireoidismo. A paciente foi submetida à tireoidectomia e um carcinoma papilar de 3,0 $\mathrm{x}$ $3,0 \times 2,0 \mathrm{~cm}$, variante folicular, foi descrito por exame histopatológico. 0 tecido tireoidiano circunjacente era normal. No pós-operatório a paciente recebeu $100 \mathrm{mCi}$ de ${ }^{131} \mathrm{l}$, e a cintilografia de corpo inteiro mostrou apenas captação residual. Nenhuma metástase foi identificada ao longo de cinco anos de acompanhamento. Nódulos quentes raramente albergam doença maligna, e este caso demonstrou que, quando ocorre carcinoma, o prognóstico parece ser muito bom, sem evidência de disseminação metastática em longo prazo. Arq Bras Endocrinol Metab. 2010;54(1):78-80
$\mathrm{T}$ hyroid cancer clinically hyperfunctioning and leading to hyperthyroidism represents a very rare condition. Less than $1 \%$ of the autonomous thyroid nodules actually harbor a malignant neoplasm (1). In the majority of cases the carcinoma coexists with a hyperfunctioning adenomatous tissue not being responsible for the toxic state of the gland (2). Until 1998, only about 20 cases of toxic thyroid carcinoma were reported in the literature, and there was a higher prevalence of the papillary type of cancer among these patients $(1,3)$. In 2002, Als and cols. (4) described a series of 19 patients with malignant hyperfunctioning nodules in Switzerland and the higher prevalence was of the follicular type of cancer. A few similar cases have been described recen- tly $(5,6)$ and the pathogenesis of this clinical condition is still unknown.

We described the case of a 47-year-old woman who had a papillary thyroid carcinoma of $3.0 \mathrm{~cm}$ of diameter, which was functionally autonomous and scintigraphically hot.

\section{CASE REPORT}

A 47-year-old woman was referred to us in May 2003, because of a thyroid nodule and hyperthyroidism. She complained of weight loss (not quantified), nervousness, tremor, fatigue and insomnia, which had begun three months earlier. Also, she had been noting a slow and progressive increase in the anterior neck region during the last two years. Her menses were regular, and 
there was a positive family history for non-neoplastic thyroid disease. There was no history of previous radiation on her cervical region. On physical examination, she weighed $54 \mathrm{~kg}$ and was $160 \mathrm{~cm}$ tall (body mass index, BMI, 21.09). Her resting pulse rate was 94 beats/ $\mathrm{min}$, and her blood pressure was $140 \times 90 \mathrm{mmHg}$. On thyroid topography, an approximately $2.5 \mathrm{~cm}$, mobile, painless nodule was palpable on the right side. No lymph nodes were detectable on examination of the neck.

Ultrasonographic study showed a solid nodule of 2.6 $\mathrm{cm}$ diameter in the right thyroid lobe, with the rest of the gland echographically normal. Scintigraphy with ${ }^{131}$ I showed the presence of an area of high iodine uptake occupying the right lobe of the thyroid, corresponding to a hyperfunctioning nodule, and no uptake was detected in the remaining bed (Figure 1A). Radioiodine uptake of the neck region was $32 \%$ after 24 hours (normal range, $10 \%-45 \%$ ). Free $\mathrm{T}_{4}$ serum levels were 2.75 $\mathrm{ng} / \mathrm{dL}$ (normal range, 0.7-1.5 ng/dL), total $\mathrm{T}_{3}$ was $3.53 \mathrm{ng} / \mathrm{mL}$ (normal range, $0.7-2.2 \mathrm{ng} / \mathrm{mL}$ ) and TSH was less than $0.05 \mathrm{mUI} / \mathrm{mL}$ (normal range, $0.3-5.0$ $\mathrm{mUI} / \mathrm{mL}$ ). On the basis of these findings, a diagnosis of an autonomously functioning thyroid nodule was made.

The patient was also submitted to a fine-needle aspiration biopsy of the nodule that was suggestive of a papillary carcinoma (Figure 1B). Methimazole therapy was initiated $(40 \mathrm{mg} /$ day) and after two months the patient was in euthyroidism. In August 2003, total thyroidectomy was performed and the postoperative course presented no complications.

Histological examination confirmed that the nodule, measuring $3.0 \times 3.0 \times 2.0 \mathrm{~cm}$ was a papillary carcinoma, follicular variant, with capsular and vascular inva-

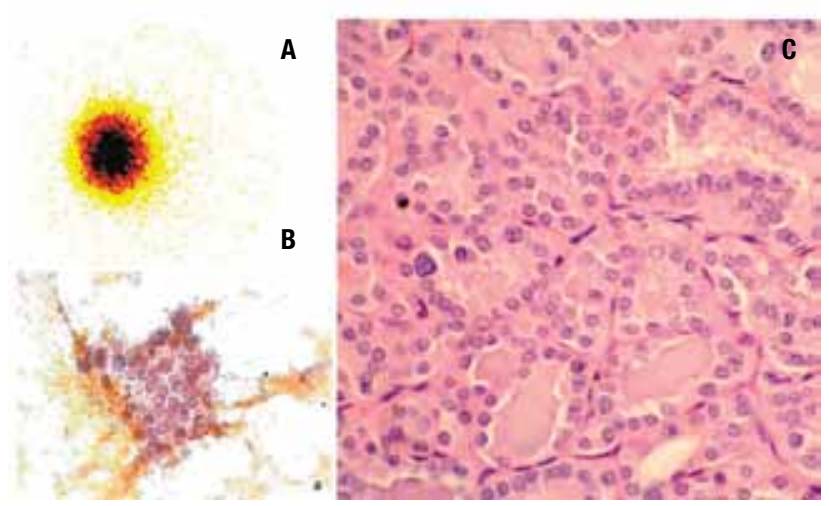

Figure 1. (A) Thyroid ${ }^{131} 1$-Scintigraphy shows a hyperfunctioning nodule in the right lobe; (B) aspirate smears show follicular clusters of cells with large and pale nuclei, and rare intranuclear inclusions; (C) histologic sections revealed a papillary carcinoma, follicular variant. sion (Figure 1C). The tumor was not multicentric, and the rest of the thyroid gland was histologically normal.

Two months after surgery the patient was in frank hypothyroidism and a $100 \mathrm{mCi}{ }^{131} \mathrm{I}$ dose was administered. ${ }^{131}$ I whole-body scan showed only some uptake in the cervical area. Subsequently, levothyroxine was instituted in a dose of $150 \mu \mathrm{g}$ per day to suppress the TSH production by the pituitary gland. One year after surgery a ${ }^{131}$ I whole-body scan was performed and again only residual uptake in the cervical area was observed. Thyroglobulin levels measured on hypothyroidism, were undetectable and antithyroglobulin antibodies were negative. The patient was maintained on levothyroxine suppressive therapy and three years after surgery cervical ultrasonography showed a heterogeneous oval nodule with internal calcifications, measuring $7 \times 12$ $\mathrm{mm}$, localized on thyroid topography. Fine needle aspiration biopsy was negative for malignancy and thyroglobulin measured in the aspirate washout was $0.2 \mathrm{ng} /$ $\mathrm{dL}$. At that time, thyroglobulin serum levels were 0.4 $\mathrm{ng} / \mathrm{mL}$, serum antibodies were negative and no intervention was performed. The dose of levothyroxine was reduced to $125 \mu \mathrm{g} /$ day and no evidence of recurrence of the disease was observed during the next two years of follow-up, once thyroglobulin and antithyroglobulin antibodies were undetectable in the patient serum.

\section{DISCUSSION}

The hyperfunctioning thyroid nodule has been generally considered a benign disease requiring a conservative therapeutic approach and in the past it was believed that hyperthyroidism excluded the possibility of a thyroid carcinoma. However, in the last years, there has been citation of cases of thyroid cancer associated with solitary toxic goiter, multinodular toxic goiter, diffuse toxic goiter (Graves' disease) and hyperfunctioning thyroid metastases (3,7-12).

We described here the case of a hyperthyroid woman who had a diagnostic suspicion of thyroid carcinoma in a fine-needle aspiration biopsy which is a very uncommon feature. The literature reports a crescent number of cases of hyperthyroidism associated with thyroid microcarcinomas diagnosticated after histopathological examination, while malignant tumors of more than $1.5 \mathrm{~cm}$ diameter, which are proved to be autonomous, are very rare. The most frequent histological type of cancer in these cases seems to be the papillary $(70 \%$ to $75 \%)$, followed by the follicular type (20\% to $25 \%)$. Medullary and anaplastic forms are rarely observed (7). 
In a five-year follow-up, our patient presented no evidence of metastases. The age at diagnosis, sex, histopathologic type (a papillary carcinoma), and low diameter of the tumor (less than $4 \mathrm{~cm}$ ) were probably distinguished characteristics that contributed to the good outcome in this period. In the previous analysis of 19 patients followed-up for a median duration of 6 years, frequency of locoregional and distant metastases did not differ from differentiated thyroid carcinomas in general (4). The survival prognosis was close to that of matched follicular subtypes of differentiated thyroid cancer (4). In the same study, 4 out of 19 patients harbored a papillary carcinoma and 2 of them were follicular variants. The first was a 56-year-old man who presented a carcinoma T2N0M0 at the initial stage with no evidence of distant metastases during 17 years of follow-up. The second patient was also a man, who had the diagnosis at the age of 74 and the tumor was a T4N0M0. He presented distant metastases during follow-up, and after six years he was still alive (4). The etiopathogenesis of coexisting hyperthyroidism and carcinoma is still unknown. Concerning autonomous thyroid adenomas, mutations in the TSH receptor gene (TSHR) and in the Gs $\alpha$ protein gene (GNASI) have been identified to be the cause of the majority of the cases $(13,14)$. Also, in hyperfunctioning carcinomas mutations in the TSH receptor gene have been described (6,15-17). However, from the data available in the literature, it seems that activation of the cAMP pathway is not a major player in cell transformation. Most hyperfunctioning tumors harbor both TSHR mutations and proto-oncogene mutations. This coexistence suggests that carcinomas arise from the activity of classical oncogenes such as RAS and RET/PTC, and that the TSHR and GNASI mutations confer hyperfunctioning features to the neoplasms (18). In the present study, we did not investigate the possibility of mutations that could be related to the pathogenesis of the disease.

Considering the rarity of the association of thyroid cancer and hyperthyroidism, at present, the evidences available are not enough to recommend the systematic evaluation of oncological risk in all hot thyroid nodes, which may be cumbersome and not necessarily cost-effective. Further studies would be helpful to clarify this issue.

In conclusion, the present report illustrates that hyperthyroidism does not exclude thyroid malignancy and confirms other published cases in which the prognosis of the carcinoma seems to be very good, with elevated survival rates, especially in the papillary histological subtype.
Disclosure: no potential conflict of interest relevant to this article was reported.

\section{REFERENCES}

1. Paul SJ, Sisson JC. Thyrotoxicosis caused by thyroid cancer. Endocrinol Metab Clin North Am. 1990;19(3):593-612.

2. Calegaro JUM, Dias MSO, Bae SH, Moraes SS, Gomes EF, Casulari LA. Papillary carcinoma of the thyroid in an autonomously functioning nodule. Arq Bras Endocrinol Metab. 2003;47(6):739-43.

3. De Rosa G, Testa A, Maurizi M, Satta MA, Aimoni C, Artuso A, et al. Thyroid carcinoma mimicking a toxic adenoma. Eur $\mathrm{J}$ Nucl Med. 1990;17(3-4):179-84.

4. Als C, Gedeon P, Rosler H, Minder C, Netzer P, Laissue JA. Survival analysis of 19 patients with toxic thyroid carcinoma. J Clin Endocrinol Metab. 2002;87(9):4122-7.

5. Fuhrer D, Tannapfel A, Sabri O, Lamesch P, Paschke R. Two somatic TSH receptor mutations in a patient with toxic metastasising follicular thyroid carcinoma and non-functional lung metastases. Endocr Relat Cancer. 2003;10(4):591-600.

6. Gozu H, Avsar M, Bircan R, Sahin S, Ahiskanali R, Gulluoglu B, et al. Does a Leu 512 Arg thyrotropin receptor mutation cause an autonomously functioning papillary carcinoma? Thyroid. 2004;14(11):975-80.

7. Mazzaferri EL.Thyroid cancer and Graves' disease. J Clin Endocrinol Metab. 1990;70(4):826-9.

8. Chao TC, Lin JD, Jeng LB, Chen MF. Thyroid cancer with concurrent hyperthyroidism. Arch Surg. 1999;134(2):130-4.

9. Gross JL, Vasques Moraes I. Thyroid hormone-producing metastases in differentiated thyroid cancer. J Endocrinol Invest. 1996;19(1):21-4.

10. Zanella E, Rulli F, Sianesi M, Sciacchitano S, Danese D, Pontecorvi $A$, et al. Hyperthyroidism with concurrent thyroid cancer. Ann Ital Chir. 2001;72(3):293-7.

11. Rubenfeld S, Wheeler TM. Thyroid cancer presenting as a hot thyroid nodule: report of a case and review of the literature. Thyroidology. 1988;(1):63-8.

12. Kim TS, Asato R, Akamizu T, Harada D, Nakashima Y, Higashi T, et al. A rare case of hyperfunctioning papillary carcinoma of the thyroid gland. Acta Otolaryngol Suppl. 2007(557):55-7.

13. Parma J, Duprez L, Van Sande J, Cochaux P, Gervy C, Mockel J, et al. Somatic mutations in the thyrotropin receptor gene cause hyperfunctioning thyroid adenomas. Nature. 1993;365(6447):649-51.

14. Trulzsch B, Krohn K, Wonerow P, Chey S, Holzapfel HP, Ackermann $F$, et al. Detection of thyroid-stimulating hormone receptor and Gsalpha mutations: in 75 toxic thyroid nodules by denaturing gradient gel electrophoresis. J Mol Med. 2001;78(12):684-91.

15. Camacho P, Gordon D, Chiefari E, Yong S, DeJong S, Pitale S, et al. A Phe 486 thyrotropin receptor mutation in an autonomously functioning follicular carcinoma that was causing hyperthyroidism. Thyroid. 2000;10(11):1009-12.

16. Niepomniszcze H, Suarez H, Pitoia F, Pignatta A, Danilowicz K, Manavela $M$, et al. Follicular carcinoma presenting as autonomous functioning thyroid nodule and containing an activating mutation of the TSH receptor (T620I) and a mutation of the Ki-RAS (G12C) genes. Thyroid. 2006;16(5):497-503.

17. Russo D, Wong MG, Costante G, Chiefari E, Treseler PA, Arturi F, et al. A Val 677 activating mutation of the thyrotropin receptor in a Hurthle cell thyroid carcinoma associated with thyrotoxicosis. Thyroid. 1999;9(1):13-7.

18. Sobrinho-Simoes M, Maximo V, Rocha AS, Trovisco V, Castro $P$, Preto $A$, et al. Intragenic mutations in thyroid cancer. Endocrinol Metab Clin North Am. 2008;37(2):333-62, viii. 